\title{
ŁUKASZ MAKOWSKI
}

Prezes Sekcji Amerykanistycznej SKNH

Uniwersytet w Białymstoku

e-mail: niedzwiedz_90@onet.eu

\section{SPRAWOZDANIE ZE STUDENCKO-DOKTORANCKIEJ KONFERENCJI NAUKOWEJ „CZAS WOJNY, CZAS POKOJU - STANY ZJEDNOCZONE AMERYKI W XX I XXI WIEKU”}

W dniu 6 czerwca 2014 r. w auli Biblioteki Uniwersyteckiej im. Jerzego Giedroycia w Białymstoku odbyła się studencko-doktorancka konferencja naukowa zatytułowana: „Czas wojny, czas pokoju - Stany Zjednoczone Ameryki w XX i XXI wieku”. Była to druga z cyklu konferencji poświęconych Stanom Zjednoczonym (poprzednia obejmowała XIX w.).

Wspomniane konferencje zostały zorganizowane prze studentów z Sekcji Amerykanistycznej Studenckiego Koła Naukowego Historyków Uniwersytetu w Białymstoku oraz opiekuna naukowego Sekcji dr Łukasza Niewińskiego. Wsparcia obu konferencjom udzielił Instytut Historii i Nauk Politycznych UwB, a w szczególności Katedra Historii 1918-1945. Kierowniczka katedry Prof. Halina Parafianowicz patronowała całemu przedsięwzięciu. Zarówno pierwsza, jak i druga konferencja cieszyły się dużym zainteresowaniem ze strony prelegentów oraz uczestników.

Celem konferencji było zaprezentowanie szerszej publiczności osiągnięć i rezultatów badań młodych historyków nad dziejami Stanów Zjednoczonych Ameryki oraz zaprezentowanie Uniwersytetu w Białymstoku jako ważnego ośrodka w Polsce prowadzącego badania nad historią USA.

W tym roku zostało zakwalifikowanych do wygłoszenia 18 referatów, które podzielono na dwa panele dyskusyjne: „Czas wojny” i „Czas pokoju”. Blisko 
połowa referatów była autorstwa studentów i pracowników Uniwersytetu w Białymstoku. Na konferencji wystąpili również reprezentanci następujących uniwersytetów: Uniwersytetu Jagiellońskiego, Uniwersytetu Gdańskiego, Uniwersytetu Wrocławskiego, Uniwersytetu Łódzkiego oraz Uniwersytetu im. Adama Mickiewicza w Poznaniu.

Uroczystą inaugurację konferencji poprowadziły prodziekan Wydziału Historyczno-Socjologicznego ds. nauki Prof. Joanna Sadowska oraz Prof. Halina Parafianowicz. Następnie opiekun naukowy Sekcji Amerykanistycznej SKNH dr Łukasz Niewiński zaprezentował publikację pokonferencyjną, zawierającą referaty przedstawione w trakcie zeszłorocznej edycji konferencji pt. „Czas wojny, czas pokoju - Stany Zjednoczone Ameryki w XIX wieku”. Każdej obecnej osobie, której referat zamieszczono we wspomnianej publikacji, wręczono jej egzemplarz.

Wykład inauguracyjny na temat „Studenckiego ruchu antywojennego w latach sześćdziesiątych", otwierający merytoryczną część konferencji wygłosił Prof. Włodzimierz Batóg (Uniwersytet Jana Kochanowskiego w Kielcach). Następnie Pan Profesor Batóg poprowadził obrady w pierwszym panelu „Czas wojny".

Wystąpienia prelegentów odznaczały się wysokim poziomem merytorycznym oraz szerokim zakresem tematycznym. W tym panelu na szczególną uwagę zasługiwały wystąpienia: mgr Łukasza Bajkowskiego (Uniwersytet w Białymstoku) „Amerykańska okupacja Haiti według króla wyspy La Gonave”, mgr Macieja Stromskiego (Uniwersytet Gdański) „Camp Hearne - historia i archeologia amerykańskiego obozu jenieckiego dla żołnierzy Afrika Korps”, Marcina Mokrosińskiego (Uniwersytet Gdański) „Koncern General Motors podczas II wojny światowej" oraz Mateusza Sztukowskiego (Uniwersytet w Białymstoku) „II wojna światowa w wybranych filmach amerykańskich”. Pozostałe, równie interesujące przemówienia, dotyczyły m.in.: amerykańskiego lotnictwa myśliwskiego w II wojnie światowej, poruszały tematykę wojny w Wietnamie, a także analizowały utwory muzyczne pojawiające się $\mathrm{w}$ trakcie amerykańskich konfliktów zbrojnych w XX w.

Kolejny panel „Czas pokoju” moderowali dr Łukasz Niewiński oraz dr Anna Stocka (Uniwersytet w Białymstoku). Zakres tematyczny wystąpień w tym panelu, przyćmiły swą różnorodnością panel wojenny. Począwszy od zarysu historii futbolu amerykańskiego, poprzez obraz Stanów Zjednoczonych w twórczości George’a Tookera, skończywszy na problematyce amerykańskiej w „Tygodniku Mód i Powieści” w latach 1900-1914. Interesujące były też wystąpienia 
Urszuli Topczewskiej (Uniwersytet w Białymstoku), „Pin-up girl w kulturze amerykańskiej”, mgr Ewy Maj (Uniwersytet Wrocławski), „, Antywojenne i pokojowe aspekty wojny Johnsona w polskiej propagandzie", mgr Vadzima Pauliuchuka (Uniwersytet w Białymstoku), „Reemigracja ze Stanów Zjednoczonych do Polski w okresie międzywojennym" oraz dr Łukasza Niewińskiego (Uniwersytet w Białymstoku) „ «Czarni rebelianci». Afroamerykanie w obronie flagi Konfederacji”.

Każde wystąpienie wywołało ożywioną dyskusję, podczas której referenci odpowiadali na pytania słuchaczy i tym samym rozwijali podejmowane przez siebie tematy. Dyskusja umożliwiła także przekazanie przez słuchaczy cennych uwag warsztatowych prelegentom.

Patronat nad przedsięwzięciem objęły następujące instytucje: HistMag.org, TVP Białystok, Polskie Radio Białystok, Radio Akadera, Gazeta.pl Białystok, Muzeum Podlaskie w Białymstoku, Wydział Historyczno-Socjologiczny UwB, Biblioteka Uniwersytecka im. Jerzego Giedroycia, Instytut Historii i Nauk Politycznych UwB, oraz SKNH UwB. 